Portland State University

PDXScholar

6-11-2021

\title{
When I Was a Young Girl: Gender and Race in The Life Archives of Criminal Transportation
}

Nick Townsend

Portland State University

Follow this and additional works at: https://pdxscholar.library.pdx.edu/honorstheses

Part of the Civil Rights and Discrimination Commons, Criminal Procedure Commons, Criminology and Criminal Justice Commons, and the History of Gender Commons Let us know how access to this document benefits you.

\section{Recommended Citation}

Townsend, Nick, "When I Was a Young Girl: Gender and Race in The Life Archives of Criminal Transportation" (2021). University Honors Theses. Paper 1105.

https://doi.org/10.15760/honors.1132

This Thesis is brought to you for free and open access. It has been accepted for inclusion in University Honors Theses by an authorized administrator of PDXScholar. Please contact us if we can make this document more accessible: pdxscholar@pdx.edu. 


\title{
WHEN I WAS A YOUNG GIRL:
}

GENDER AND RACE IN THE LIFE ARCHIVES OF CRIMINAL TRANSPORTATION

\author{
by \\ NICK TOWNSEND
}

A thesis submitted in partial fulfillment of the requirements for the degree of

BACHELOR OF ARTS WITH HONORS

in HISTORY

Portland State University 2021 


\begin{abstract}
In the eighteenth and nineteenth century, the carceral system in England shifted away from corporal punishment and moved towards containing and policing those deemed criminal in different ways. One notable way was transportation, the practice of moving convicts out of the imperial core into a colony. This practice became a way to remove "lesser" populations from England and regulate social behavior while also expanding the British Empire and allowed convicts a new purpose in expanding the carceral state. This developed alongside the broader trends of racialization and colonization in the British Empire, which drew a global color line separating "white" and "colored" and maintained a distinction between the two populations. This thesis considers the case of two women sentenced to criminal transportation, Elizabeth Hincks and Charlotte Brown. Hincks and Brown were accused of stealing a silver watch from a drunkard, and are heavily implied to be prostitutes in the trial transcript. Both were found guilty and sentenced to transportation, but only Hincks was actually sent to Australia. The archival traces created by their interactions with the criminal and legal systems are considered in the context of a transnational empire looking to restrict and reform white femininity.
\end{abstract}




\section{Acknowledgments}

I would like to sincerely thank my thesis supervisor Patricia Schechter for her patience, fortitude, and willingness to constantly extend deadlines in the face of a global pandemic. I would also like to thank Tom Luckett, who coordinated the departmental honors program, and Nicole Dressler, who sent me a full copy of her Oxford bibliography on convict transportation. Finally, I thank

my parents, who not only gave me the ability to go to college and choose my own path, but the skills necessary to do so successfully. 


\section{Table of Contents}

Acknowledgements...3

Table of Contents...3

The Carceral System in England...5

Deviant Women and Disease Anxiety...7

Transportation: Reform Abroad...10

Settler Colonialism and Gendered Communities...15

Identity in the Life Archive...22

Case Study: Elizabeth Hincks and Charlotte (Charlotee) Brown...30

Conclusion: The Limits of a Reconstructed Life...39

Bibliography...41 


\section{The Carceral System in England}

Study of crime and the courts in England dates back to contemporary thoughts and notes records by British thinkers and intellectuals at the time, but serious academic inquiry into crime and its relationship to society owes its origins to the social historian movement of the 1960-70s, who hoped to use criminal records as a place to gain information about the lives and behaviors of general men and women who do not usually appear in the archive. ${ }^{1}$ In this endeavor they were very successful, producing volumes and volumes of work on the massive rolls and registers that British bureaucracy created in the process of producing criminality and punishment.

The modern scholarly works from this period all rely on the foundational text on crime and transportation: J.M. Beatie's Crime and the Courts in England 1660-1800. Starting with the period of reformation and ending just before the case study of this thesis, Beatie's work is a comprehensive overview of the trial and conviction process in the English court system, with special attention on the counties Surrey and Sussex. For our purposes, his most relevant section is chapter nine: "Punishment, 1660-1750: the impact of transportation." Beatie describes the development of transportation as an "expedient" to the growing dissatisfaction of the public and on the bench with the judge's lack of secondary options to hanging. Before 1718 , most convicts only option to escape capital punishment was to appeal to a clergymember, who could accept the appeal and have their sentence reduced down to simply being branded on the thumb. According to Beatie, many convicts did so and were able to escape a perfunctory execution. But many also weren't, and those who found themselves disdained by either their clergy or judge would almost certainly face death, as both parties had total discretion to deny appeals. ${ }^{2}$

\footnotetext{
${ }^{1}$ J. M. Beattie, Crime and the Courts in England: 1660 - 1800 (Oxford: Clarendon [u.a.], 1986), 3.

${ }^{2}$ Beattie, Crime and the Courts in England, 450-52.
} 
This system had many contemporary detractors. Members of the government and the public decried the brandings as simply releasing habitual offenders back into society. Beatie also cites a "disinclination in the courts" to send as many offenders to the gallows in the late 1600 s, suggesting a change in attitudes from corporal toward capital punishment. Transportation provided a way that certain threats could be "disposed of without being hanged."There was also a public attitude that the clergy appeal process didn't present an effective deterrent to crime, even though many convicts would end up whipped, flogged, or hanged in public courtyards. Public punishments served an attempted "renewal of community values by their recognition and disapproval of the deviant act," in Beatie's view. As this was phased out and replaced with transportation and jailing, it marked the beginning in a gradual shift toward moving and containing bodies rather than physically punishing them. ${ }^{3}$

Transportation would come to take a similar role in the public eye as public flogging, serving both as a spectacle of state power and morality tale. Although it was the state carrying out the punishment, the community was instrumental in doling it out through the collective stigma of transportation, evidenced in the tradition of the transportation ballad and public lectures on the "horrors of transportation." Interestingly, this shift away from capital punishment made the convict themself part of the collective detterence machine, as in the case of John Brocksopp, a convict who was transported to Australia for 15 years and later gave went on a public lecture tour on transportation, embellishing his experience with costume and performance of labor and whipping. ${ }^{4}$ For men, convict transportation could present opportunities to become a redeemed rugged woodsman, who had survived the trials of transportation and the bush and lived

\footnotetext{
${ }^{3}$ Beattie, 473.

${ }^{4}$ Unknown, "Broadside about a Lecture 'on the Horrors of Transportation,"” 1849, British Library.
} 
to tell the tale. For women, transportation was much murkier and steeped in discourses of deviance, prostitution, and disease.

\section{Deviant Women and Disease Anxiety}

Scholars only began to write on a large scale on deviant women, and specifically transported woman, in the 1970 s, when feminist historians introduced gender as a category of analysis in countless disciplines and subdiscplines. ${ }^{5}$ It's in this period that female criminals moved from being a historical oddity to a subject worth serious inquiry. Yet it took still more time for crime historians in Britain to seriously consider women as subjects, partly because they represent a smaller portion of the criminal record and partly because the kinds of crimes women commit do not make their way into the record as readily as male-gendered crimes like highway robbery and poaching. ${ }^{6}$ Recent work since the 1990s has uncovered increasing information about women put before the court in England, revealing patterns that both confirm and reject certain public biases. What scholars of crime and gender like Beatie, King, and Arnot have shown is a consistent conviction and sentencing disparity between men and women. A study of property crime offenders between $1780-1820$ by Peter King found that $61 \%$ of men were found guilty, while only $41 \%$ of women were, making men $40 \%$ more likely to face conviction than a similar female offender. Factors for this include not just a leniency of judges and juries, but also a

\footnotetext{
${ }^{5}$ Joan W. Scott, "Gender: A Useful Category of Historical Analysis," The American Historical Review 91, no. 5 (1986): 1053-75, https://doi.org/10.2307/1864376; Frances Heidensohn, "The Deviance of Women: A Critique and an Enquiry: The Deviance of Women," The British Journal of Sociology 61 (January 14, 2010): 111-26, https://doi.org/10.1111/j.1468-4446.2009.01242.x.

${ }^{6}$ Meg Arnot, Margaret L Arnot, and Cornelie Usborne, Gender and Crime in Modern Europe (London: UCL Press, 1999), 2; Clive Emsley, Tim Hitchcock, and Robert Shoemaker, "Historical Background - Gender in the Proceedings," Old Bailey Proceedings Online, accessed April 26, 2021, https://www.oldbaileyonline.org/static/Gender.jsp; Peter King, "Gender, Crime and Justice in Late Eighteenth and Early Nineteenth-Century England," in Gender and Crime in Modern Europe (London: UCL Press, 1999); Judith R. Walkowitz, Prostitution and Victorian Society: Women, Class, and the State (Cambridge ; New York: Cambridge University Press, 1980); Ruth Mazo Karras, Common Women : Prostitution and Sexuality in Medieval England (New York, UNITED STATES: Oxford University Press, Incorporated, 1996), http://ebookcentral.proquest.com/lib/psu/detail.action?docID=1591264.
} 
pattern of witnesses against female defendants not showing up in court. ${ }^{7}$ In sentencing, women were less likely to be whipped and hanged, and by 1820 the former was outlawed against women. Until 1691, women convicted of certain crimes were ineligible to plead clergy, even as men accused of the same crime were eligible. However, they were not required to take a literacy test to plead clergy, as men sometimes were. ${ }^{8}$

The sentence of transportation also had gendered dimensions. Beatie quotes one petitioner awaiting execution in 1663 who asks to be sent to the colonies instead, writing that he could be "advanced by industry, being a single man..." Another wrote that he was "unmarried and able to do good service." ${ }^{, 9}$ Despite these appeals on the basis of physical fitness and single-ness, England also transported women to colonies. In King's ten-thousand person sample, $32 \%$ of female convicted property offenders were transported, whereas $42 \%$ of male offenders were. These numbers suggest that leniency was given to some female offenders, but clearly not all. It also meant that there was a gender imbalance in Australia's penal colonies, leading to roughly $90 \%$ of transported women getting married but only roughly $25 \%$ men. $^{10}$

Much like crime and gender, sexuality and prostitution were developed into topics of historical scrutiny in the 1970s by a combination of reform-minded social historians and historians of women and gender with an activist lens. They would later be joined by queer historians, many of whom were also working as the academic arm of social movements. Because of their position in nineteenth century English society, the voices of sex workers themselves are rarely embedded in the archive. Instead, we are left with the overwhelmingly male-shaped public

\footnotetext{
${ }^{7}$ King, "Gender, Crime and Justice in Late Eighteenth and Early Nineteenth-Century England."

${ }^{8}$ Beattie, Crime and the Courts in England, 452.

${ }^{9}$ Beattie, 473.

${ }^{10}$ Elizabeth Burke, "Voices from the Old Bailey, Series 3: Transportation" (BBC Radio 4, September 4, 2014), https://www.bbc.co.uk/sounds/play/b04g10zc.
} 
perception of prostitution and the way English society used this perception to control women's bodies.

Many historical studies of prostitiution in England center their work around the passage and dramatic reaction to the 1864,1866 , and 1869 Contagious Disease Acts. The acts gave policemen in certain areas of England unprecedented powers to inspect women's bodies and contain them for months at a time without trial and hearing, on the basis of protecting English enlisted men from venereal diseases. The Acts are an important look into how nineteenth century England came to view prostitutes as diseased women who were infecting British men. ${ }^{11}$ This discourse was the result of male anxieties about impure, tainted, and irresistible women. Upper-middle class men began using proto-condoms made out of animal gut to prevent venereal disease while engaging in sex with prostitutes, and by the 1820 s and 1830 s birth control was beginning to be openly discussed. ${ }^{12}$ Recent work has also contextualized these anxieties as not just the individual anxieties of men worried about contracting disease, but also the anxieties of the empire. British officials, especially those in India, saw venereal disease as a threat to stable British colonial presence. By 1864 one-third of reported sickness in the British army was venereal in origin. By the 1890's the impact of venereal disease had formed what Levine calls a "constitutional crisis" in the British Empire. ${ }^{13}$

What's worth distinguishing is the domestic anxieties around prostitution that resulted in policing poor women's bodies and activities, and the anxieties of the empire that resulted in broader subjugation of colonized populations. In colonized populations, prostitutuion represented

\footnotetext{
${ }^{11}$ Walkowitz, Prostitution and Victorian Society; Philippa Levine, "Rereading the 1890s: Venereal Disease as 'Constitutional Crisis' in Britain and British India," The Journal of Asian Studies 55, no. 3 (1996): 585-612, https://doi.org/10.2307/2646447.

12 "Prostitution" in John Cannon and Robert Crowcroft, eds., The Oxford Companion to British History, Second edition (Oxford, United Kingdom ; New York, NY: Oxford University Press, 2015).

${ }^{13}$ Walkowitz, Prostitution and Victorian Society; Levine, "Rereading the 1890s"; Philippa Levine, Prostitution, Race, and Politics: Policing Venereal Disease in the British Empire (New York: Routledge, 2003).
} 
the clear moral failings of a lesser population while also presenting the problem of disease. In white women, "its dangers had less to do with the infection of British soldiers than with white prestige and the roles ascribed to women in white culture." This distinction meant that colonial officials had an interest in the reformation of white prostitutes that they did not have in colonized prostitutes. ${ }^{14}$ In the nineteenth century, this attempt at reforming white prostitutes increasingly came through transportation, which removed alleged prostitutes from the colonial core while allowing them to aspire to ideal white femininity through marriage and the settler-colonial family.

\section{Transportation: Reform Abroad}

From its inception, penal transportation was a tool for expanding the colonial state and utilizing "undesirable" white populations. Transportation became a former legal tool of the British criminal system in 1614-15 when James 1 issued a commission to his Privy Council giving them the authority to send certain criminals into "other services beyond the Seas" in order to "yeild a profitable service to the Comon wealth." ${ }^{15}$ Convicts reprieved under this commission were sent to the West Indies, Barbados, and Virginia to serve in the private bondage of colonial landholders. ${ }^{16}$ They served as indentured servants for private landholders and were transported to the colonies on merchant ships, making the conditional pardon down to transportation essentially a private matter once issued. However, this practice was limited mostly to political prisoners and those convicted of high treason, such as those serving the Duke of Monmouth in the Monmouth

\footnotetext{
${ }^{14}$ Levine, Prostitution, Race, and Politics, 232.

${ }^{15}$ Abbott Emerson Smith, Colonists in Bondage : White Servitude and Convict Labor in America, $1607-1776$ (Chapel Hill, UNITED STATES: University of North Carolina Press, 2012), 93, http://ebookcentral.proquest.com/lib/psu/detail.action?docID=4322215.

${ }^{16}$ Smith, 95.
} 
rebellion, several of whom left journals documenting their experiences being transported. ${ }^{17}$ The punishment became more popular, though still limited, in the second half of the seventeenth century. Although originally almost entirely imposed on men, the sentence eventually was used on women.

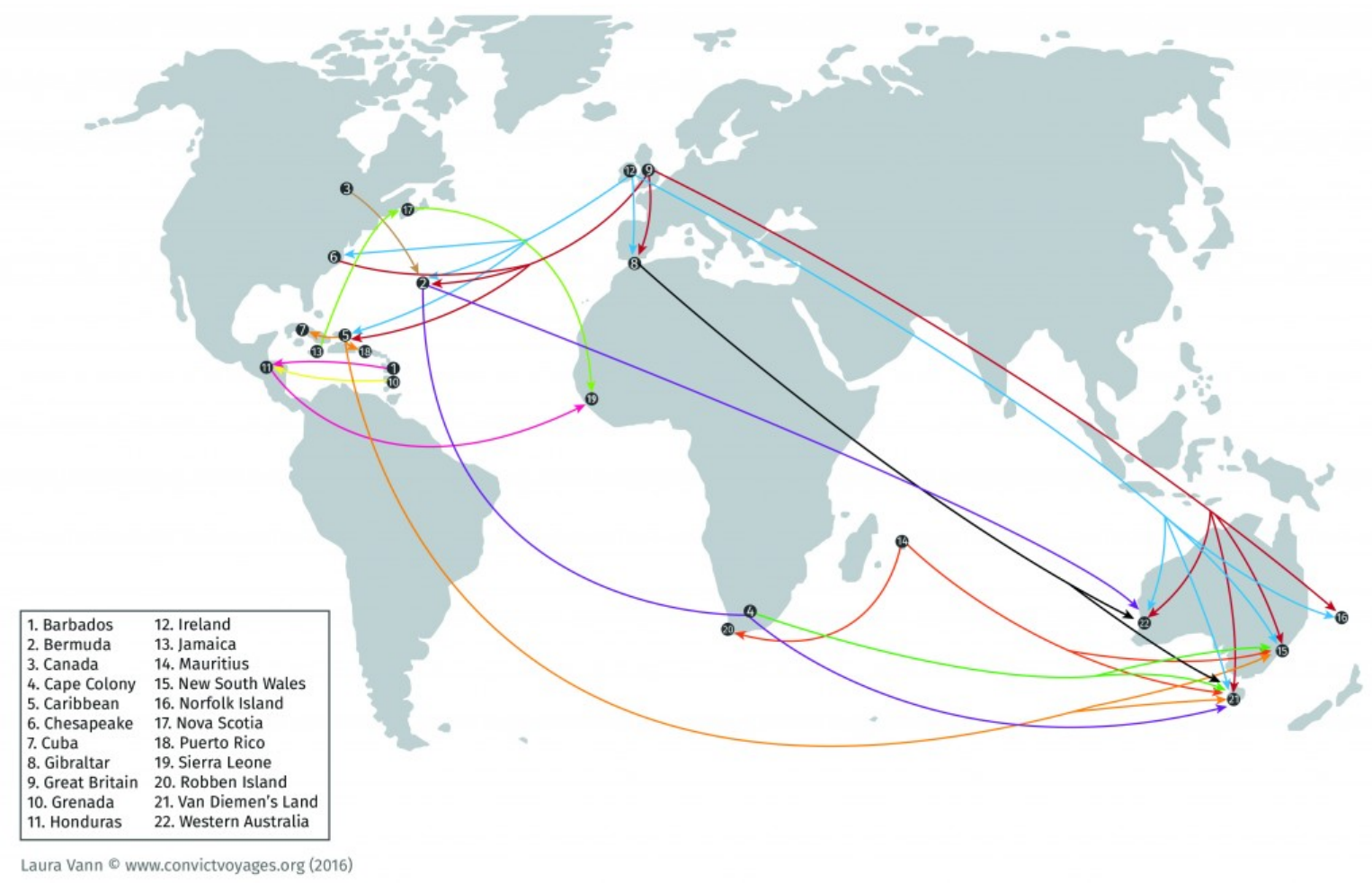

Convict Transportation in the British Empire, 1618-1874 ${ }^{18}$

In the summer of 1697 Newgate Gaol held around fifty women sentenced to

transportation with no destination set, with no private merchants contracted to take them to a

\footnotetext{
${ }^{17}$ Henry. Pitman, A Relation of the Great Sufferings and Strange Adventures of Henry Pitman, Chyrurgion to the Late Duke of Monmouth, Containing an Account ... (London, Printed by Andrew Sowle, and are to be sold by John Taylor ..., 1689),

http://stats.lib.pdx.edu/proxy.php?url=http://search.proquest.com/books/relation-great-sufferings-strange-adventures/ docview/2240855559/se-2? accountid=13265; John Coad and Chiswick Press., A Memorandum of the Wonderful Providences of God to a Poor Unworthy Creature: During the Time of the Duke of Monmouth's Rebellion and to the Revolution in 1688, xiii, 141, 14 p. (London: Longman, Brown, Green \& Longmans, 1849), //catalog.hathitrust.org/Record/000313724.

${ }^{18}$ Clare Anderson, "Transnational Histories of Penal Transportation: Punishment, Labour and Governance in the British Imperial World, 1788-1939,” Australian Historical Studies 47, no. 3 (September 1, 2016): 381-97, https://doi.org/10.1080/1031461X.2016.1203962.
} 
colony. After a remonstrance from the City of London, British officials arranged for the Admiralty to transport the fifty women, and a separate official sent letters to colonial officials asking if one of them would accept the women. Several colonies responded that, as they did not allow white women to perform labor, the women would be of no use. Officials in Jamaica responded that they would only take the women only if triple the number of men were sent over as well and remarked that the women "would only be a burden to us and would contribute nothing to our defence." New York tentatively offered to take the women if they were "young and fitted for labor" and if property holders would take responsibility for their expense. Eventually, the women ended up sent to the Leeward Islands in the Caribbean. ${ }^{19}$

This incident and several others are important in the administrative history of transportation because they demonstrated that there was no cohesive system of administering the punishment of transportation. It also demonstrates that colonies were beginning to distinguish white women from the male convicts, and from the male and female African slaves that were being worked to death in the fields of the Americas. The category of "woman," in the above incident, is tied to the race of the individual in question, and necessarily limits the labor they are capable of performing. This led to a situation in colonies like Barbados where enslaved black women worked in agriculture alongside men even as white women were prohibited from being forced into that labor. ${ }^{20}$ From its earliest days transportation was a punishment embedded in the racial caste system being created in the British empire.

Even as transportation gained popularity as a concept among the English judiciary, colonies grew reluctant to accept new convicts. Both Maryland and Virginia passed laws prohibiting convicts from being sent to the colonies in the 1670s. It wasn't until political

\footnotetext{
${ }^{19}$ Smith, Colonists in Bondage: White Servitude and Convict Labor in America, 1607-1776, 185; Beattie, Crime and the Courts in England, 481.

${ }^{20}$ Smith, 106. For more on this see Crenshaw, "Demarginalizing”, and Taylor, No Mercy Here
} 
conditions changed in both the colonies and the English mainland in the early eighteenth century that transportation was renewed as a secondary punishment and the Transportation Act of 1718 was passed by parliament. The act allowed courts to sentence felons to transportation without the complicated pleading and pardoning procedure that had marked the earlier history of transportation. Instead, courts could directly sentence felons to seven years transportation to America, sentencing those who returned before completion of their sentence to capital punishment. ${ }^{21}$ Still, the category of "criminal" worried many in colonial governments, and Maryland and Virginia legislatures drafted complicated restrictions on convict importation that made the practice difficult for merchants to navigate. They made no similar restrictions for importing African slaves. ${ }^{22}$

After the American Revolution closed Chesapeake ports to convict transportation, British officials were left with an influx of prisoners with nowhere to go. Hanging grew in popularity, doubling between the years of 1780 and 1785 , leading one contemporary observer to note that England would soon be known as the "Bloody Country." 23 A brief and ultimately disastrous attempt at sending certain male convicts to a colony in West Africa added to a crisis of dwindling penal options, as well as exacerbating anxieties about mixing white and black forced labor. ${ }^{24}$ Once Australia was found and claimed by Captain James Cook, it quickly became the primary option for a new penal colony. The First Fleet of convicts were sent to Australia in 1787 and established the colony at Botany Bay, in New South Wales. They were followed quickly by the

\footnotetext{
${ }^{21}$ Beattie 503. For more on returning from transportation see Peter Rushton and Gwenda Morgan, "Running Away and Returning Home: The Fate of English Convicts in the American Colonies," Crime, Histoire \& Sociétés / Crime, History \& Societies 7, no. Vol. 7, n² (December 1, 2003): 61-80, https://doi.org/10.4000/chs.545.

${ }^{22}$ Smith, Colonists in Bondage: White Servitude and Convict Labor in America, 1607-1776, 119; Beattie, Crime and the Courts in England.

${ }^{23}$ Beattie 585. Emma Christopher, Merciless Place: The Fate of Britain's Convicts after the American Revolution (Cary, UNITED KINGDOM: Oxford University Press, Incorporated, 2011), http://ebookcentral.proquest.com/lib/psu/detail.action?docID=829359.

${ }^{24}$ Christopher, Merciless Place.
} 
Second and Third Fleets in the next two years, establishing Australia as the primary destination for transporting convicts from England and Ireland.

Once sentenced to transportation to Australia, convicts faced a fraught journey aboard poorly regulated, overcrowded ships. In the Atlantic system preceding the American Revolution, convicts were transported by merchants who essentially owned the labor of the convicts and sold it to the highest bidder in the Americas. The merchants had a vested pecuniary interest in the safe passage of their human cargo. In transportation to Australia, the convicts served as laborers for the state, meaning there was no highest bidder. Vessels were contracted to serve voyages transporting convicts to Australia, and were paid a flat fee based on the amount of heads that embarked on the vessel. Bateson remarks that "dead convicts were more profitable than the living" due to the expense of provisions. So the incentive structure was reversed. ${ }^{25}$

The conditions on convict vessels came into the eye of the British public early in the history of Australian transportation when the second fleet of convict ships reached Australia in horrible condition in 1790 , with much higher mortality and sickness rates than the first fleet the previous year. One soldier viewing the shambling convicts disembarking went so far as to write "the slave trade is more merciful compared to what I have seen in this fleet." His remarks, as Christopher notes, have generated much historical attention for their connection between the two mass forced movements of bodies happening at the same time. He was not alone in this view, as transportation came into increasing scrutiny as the British public began to openly debate the slave trade. However, many British abolitionists rejected the comparison between the two, making an argument for slaves rooted in the politics of civility and the innocent victim deserving

\footnotetext{
${ }^{25}$ Charles Bateson, The Convict Ships, 1787-1868., [2d ed.]. (Glasgow: Brown, Son \& Ferguson, 1969).
} 
of Christian salvation. ${ }^{26}$ And so transportation remained a punishment well after the abolition of the slave trade in $1833 .{ }^{27}$

A major concern of British officials and their colonial counterparts in Australia was the supposed sexual impropriety of female convicts. Until 1811, convict ships were not rigidly separated by gender. Some vessels carried both men and women, while others carried just women or just men. ${ }^{28}$ After "segregation became the rule" in 1811, colonial officials shifted their concerns to sexual contact between female convicts and male crewmembers. Governor Arthur Philip of New South Wales wrote down his anxieties about one such relationship between a ship's surgeon and a female convict, Julia Mills. ${ }^{29}$ Christopher notes that these anxieties were bolstered by the British press. The Times published an article in 1787 before the launch of the First Fleet to Australia stating that each sailor on the fleet was allowed "to select a mate for the voyage" ${ }^{30}$ These reports, in turn, led to several sailors signing to the Second Fleet for the explicit purpose of bedding a female convict. Damousi, in "Chaos and Order: Gender, Space and Sexuality on Female Convict Ships" provides a framework for analyzing the spatial confines of female convict vessels and the way their passengers negotiated the distinctions between public and private in their sexual relationships and other matters.

\section{Settler-Colonialism and Gendered Communities}

Australia has been populated by humans for at least 30,000 years. Aborigine beliefs hold, loosely, that before man existed there was a long long period of time sometimes referred to as

\footnotetext{
${ }^{26}$ Emma Christopher, Cassandra Pybus, and Marcus Rediker, eds., Many Middle Passages: Forced Migration and the Making of the Modern World, The California World History Library 5 (Berkeley: University of California Press, 2007).

${ }^{27}$ Charles Bateson, The Convict Ships, 1787-1868., [2d ed.]. (Glasgow: Brown, Son \& Ferguson, 1969).

${ }^{28}$ Joy Damousi, "Chaos and Order: Gender, Space and Sexuality on Female Convict Ships.," Australian Historical Studies 26, no. 104 (April 1995): 351; Bateson, The Convict Ships, 1787-1868., 188.

${ }^{29}$ Damousi, "Chaos and Order: Gender, Space and Sexuality on Female Convict Ships."

${ }^{30}$ Christopher, Pybus, and Rediker, Many Middle Passages, 119.
} 
"the Dreaming" in which semi-divine entities walked the earth, shaping and manifesting the environment, and eventually creating humans and all elements of nature. ${ }^{31}$ Western anthropologists now believe that Aborigines came to Australia over a series of short sea-voyages, hopping from island to island across the Pacific. At the time when people first populated the continent, Australia was around a quarter bigger than it is today. Tasmania was connected to mainland Australia by a thin land bridge. As ice sheets melted, parts of the coast moved inland as much as three miles a year. At the same time, Aboriginal peoples spread across the continent in small nomadic groups, forming attachments to the land and the foodstuffs that they subsisted on. This lifestyle, which had gone uninterrupted for thousands of years, came to a rapid end when Europeans came to Australia. ${ }^{32}$

Although known to Europeans at least a century earlier and officially claimed on the west coast as New Holland, Australia became an interest of the British empire in 1770 when James Cook navigated the coast of eastern Australia on his first voyage, stopping in a harbor he named Botany Bay. On this trip, he noted contact with several groups of aboriginal Australians. Reflecting changing European views on nature and pastoralism, Cook wrote that the people he saw "live in a Tranquillity which is not disturb'd by the Inequality of Condition" and that they had no fixed dwellings but "move about from place to place like wild beasts in search of Food."33 An important point for Cook, his botanist Joseph Banks, and other observers was that the aboriginal Australians they encountered did not (to their eyes) perform any agriculture. Cook and

\footnotetext{
${ }^{31}$ Britannica, T. Editors of Encyclopaedia, "The Dreaming," in Encyclopedia Britannica, November 2, 2020.

${ }^{32}$ Robert Hughes, The Fatal Shore, 1st Vintage Books ed (New York: Vintage Books, 1988), 15; D.J. Mulvaney, "The Australian Aborigines 1606-1929: Opinion and Fieldwork," Historical Studies: Australia and New Zealand 8, no. 30 (May 1958): 131-51, https://doi.org/10.1080/10314615808595109; Ben Kiernan, Blood and Soil: A World History of Genocide and Extermination from Sparta to Darfur (New Haven, Conn. London: Yale University Press, 2009), chap. 7.

${ }^{33}$ Kiernan, Blood and Soil, 249; James Cook, Captain Cook's Journal During His First Voyage Round the World Made in H. M. Bark "Endeavour", $1768-71$ (Project Gutenberg, n.d.).
} 
his crew interacted very little and un-substantively with the aboriginal Australians, but they were among the first of many to introduce smallpox, measles, and tuberculosis to the continent.

The immediate result of European contact was the same as it had been in North America two centuries earlier: death. Although estimates of native populations before settler colonialism are always crude and reflect colonial knowledge of indigenous populations, it is safe to assert that European diseases imposed mass death and disaster on Aborigines as they did previously on Native Americans. In 1788 when the First Fleet disembarked in New South Wales there were about 500,000-750,000 Aborigines. By 1901 there were fewer than 100,000. The impact of diseases on the Aboriginal population can not be overstated, but they did not operate without the support of European violence, responsible for some 20,000 deaths. ${ }^{34}$ Genocide scholar Ben Kiernan writes that although official British imperial policy was to treat Aborigines with "amity and kindness," there were no rights granted to land, compensation or represetnatition. As a consequence the "laissez-faire" policy towards indigenous protection meant that the crown "usually failed" to protect indigenous subjects from mass murder and later, starvation. ${ }^{35}$

Although complicated by the blurred line between convict and settler, Australia was still a settler colonial society. Settler colonialism's target is not individuals of a specific ethnicity, but the collective as a structure capable of resisting further incursion and homogenizing. . In order to accommodate land titles of the settler population, a handful of strategies toward aboriginals, including assimilation, deportation, and outright genocide came to the forefront of colonial policy. This structure of invasion, referred to by Wolfe as "the logic of elimination," forms the basis of settler strategy towards indigenous populations. ${ }^{36}$ In Australia, this began as sporadic

\footnotetext{
${ }^{34}$ Kiernan, Blood and Soil.

${ }^{35}$ Kiernan, 251; Benjamin Madley, "From Terror to Genocide: Britain's Tasmanian Penal Colony and Australia's History Wars," Journal of British Studies 47, no. 1 (2008): 77-106.

${ }^{36}$ Patrick Wolfe, "Settler Colonialism and the Elimination of the Native," Journal of Genocide Research 8, no. 4 (December 2006): 402, https://doi.org/10.1080/14623520601056240.
} 
conflicts and negotiations between Aborigines and British settlers. The first governor of New South Wales, Arthur Philip, tried to "reach accommodation" with Aborigines, but predecessors pursued more violent strategies. Philip King, governor from 1801-1806, commuted the death sentences of five farmers tried for the murder of Aborigines, setting a precedent of impunity for violence against Aborigines. ${ }^{37}$

The ongoing structure of settler colonialism also bears on the gender formation of both settler and native. Glenn has argued, in the case of America, that settler colonialism is a race-gender project that transplants "certain racialized and gendered conceptions and regimes from the metropole" and adapts them to suit the particular needs and experiences of the colony. She argues boarding schools that worked to "civilize" Native American served as a strategy of forcing indigenous children into traditional European gender roles. This would later become the case in Australia when the government sought to "absorb the Aborigines" and instituted similar practices. ${ }^{38}$ In Australia, the roots of this system were shaped by the colony's convict system and the lawlessness of the bush. Early traces of this can be seen in the practice of released and escaped convicts taking Aborigine children away from their families, either as "adoptive" children or as forced laborers. ${ }^{39}$

It was in this contentious and at times genocidal environment that the female convict ships docked in Botany Bay from England, depositing their load of human cargo onto the receded shore. It was in this settler colonial system that gender norms were imposed on female convicts and in turn shaped and resisted by them. The unique nature of Australia as a convict

\footnotetext{
${ }^{37}$ Kiernan, Blood and Soil, 255.

38 “Absorb The Aborigines, Says Expert," Herald (Melbourne, Vic. : 1861 - 1954) (Melbourne, Vic., January 13 , 1949), http://nla.gov.au/nla.news-article247723979.

${ }^{39}$ Evelyn Nakano Glenn, "Settler Colonialism as Structure: A Framework for Comparative Studies of U.S. Race and Gender Formation," Sociology of Race and Ethnicity 1, no. 1 (2015): 52-72, https://doi.org/10.1177/2332649214560440; Kiernan, Blood and Soil, 255; Madley, "From Terror to Genocide: Britain’s Tasmanian Penal Colony and Australia’s History Wars.”
} 
colony had a significant bearing on this gender, sexuality, and family formation as well. In the words of Hughes "the sexism of English society was brought to Australia and then amplified by penal conditions. ${ }^{40}$ In other settler societies like America, the white woman was quickly developed into a figure representing "domesticity and dependency" and the idealized version of femininity. ${ }^{41}$ In Australia, the same did not happen. Instead, white Australian women were cast as whores, prostitutes, and degenerates who had to be shaped into acceptable wives and mothers. While the wives and families of elite British officers and administrators were afforded a level of respectability and influence, the environment for most women was one of "striking sexual exploitation," in the words of Jill Conway, Australian gender historian. ${ }^{42}$

This environment was the result of, in part, the massive gender imbalance in early Australia. Roughly 24,000 women were transported to Australia between 1788 and 1852, only about $1 / 7$ or $16 \%$ of the total amount of transports in the period..$^{43}$ The result was that women became a commodity, in the eyes of male sailors, convicts, settlers, and the public. The public image of the transported convict woman as a whore extends back to the inception of Australian transportation, when the ship Lady Julian (launched 1789) was labelled a "floating brothel” by the British press. ${ }^{44}$ More recent work has shown that women on convict ships engaged in deliberate negotiation of space and relationships, as well as using "their relationships with one or more men to extract material benefits," rather than being passive recipients of unwanted

\footnotetext{
${ }^{40}$ Hughes, The Fatal Shore, 258.

${ }^{41}$ Sarah Haley, No Mercy Here: Gender, Punishment, and the Making of Jim Crow Modernity, Justice, Power, and Politics (Chapel Hill: The University of North Carolina Press, 2016); Stephanie E. Jones-Rogers, They Were Her Property: White Women as Slave Owners in the American South (New Haven ; London: Yale University Press, 2019); Glenn, "Settler Colonialism as Structure: A Framework for Comparative Studies of U.S. Race and Gender Formation.”

42 Jill Conway, "Gender in Australia," Daedalus, 1985, 343-68; Ann Curthoys, "Gender Studies in Australia: A History," Australian Feminist Studies 15, no. 31 (2000): 19-38.

${ }^{43}$ Conway, "Gender in Australia"; Hughes, The Fatal Shore, 244.

${ }^{44}$ Siân Rees, The Floating Brothel: The Extraordinary True Story of an Eighteenth-Century Ship and Its Cargo of Female Convicts, 1st ed. (New York, N.Y.: Hyperion, 2002); Christopher, Pybus, and Rediker, Many Middle Passages.
} 
advances from shipmen. ${ }^{45}$ The same was true in the Australian colonies, where disembarking women were "to set themselves off to the best advantage" by being picked to cohabitate with upstanding men. ${ }^{46}$

When female convict ships arrived in Australia during the early period of transportation, women were "assigned" a position in the colony, formally as a domestic servant. In practice, this assignment could range anywhere from servant to sex slave to common law wife. Military officers were given the first pick of the disembarking convicts, and then other soldiers, and then free and freed convicts who were given the governor's permission. ${ }^{47}$ Even women who were not assigned to men as servants frequently cohabitated and had sexual liaisons with free and freed settlers, as the colony itself did not have adequate accommodations for its female convicts. Hughes notes that there was some moral panic about the assignment system rendering the colony an "extensive brothel," but that the economic incentive of keeping women off the government's expense rolls and granaries kept early governors from reforming the system. ${ }^{48}$

What accommodation the colonial government did provide to women was indicative of the expectations of womanhood in the colony. Those women who were not chosen for assignment were sent to the Female Factory, first in Parramatta and then in Hobart, to spin wool into yarn to create winter clothes for convicts. The Parramatta factory was a "scene of disgusting squalor," where women slept on unspun wool, were given insufficient rations, and water leaked through the rotten floorboards onto the heads of prisoners detained in cells beneath the factory floor. In this environment a cycle of resistance and retaliation developed. Women developed coping strategies and engaged in behaviors like prostitution and homesexuality as a means of

\footnotetext{
${ }^{45}$ Damousi, "Chaos and Order: Gender, Space and Sexuality on Female Convict Ships."; Raelene Frances, Selling Sex : A Hidden History of Prostitution (Sydney, AUSTRALIA: University of NSW Press, 2007), http://ebookcentral.proquest.com/lib/psu/detail.action?docID=421330.

${ }^{46}$ Hughes, The Fatal Shore, 253.

${ }^{47}$ Frances, Selling Sex : A Hidden History of Prostitution, 14; Hughes, The Fatal Shore, 253.

${ }^{48}$ Hughes, The Fatal Shore, 253.
} 
both survival and resistance. Colonial officials responded with scrutiny and the feared ritual of humiliation and defeminization: head shaving. ${ }^{49}$

Both the assignment system and the Female Factories show the impact of gendered societal expectations on the female convicts. Whereas male convicts were expected to labor as convicts, women were expected to labor, but also to do the necessary domestic labor to keep the colony and their assigned household operational. In some assignments, women became the "de facto" wives of their assignees, in part because the work of a domestic servant so closely mirrored the duties of a wife. ${ }^{50}$ A unmarried woman who cohabitated with a man, out of want or necessity, was labelled a prostitute and became part of the rhetoric of the "depravity and disorder" of the new colony. ${ }^{51}$ In New South Wales, marriage became an institution through which both male and female convicts could gain some measure of social recognition and power.

\footnotetext{
${ }^{49}$ Bláthnaid Nolan, "Up Close and Personal: Lesbian Sub-Culture in the Female Factories of Van Diemen's Land.," Journal of Lesbian Studies 17, no. 3/4 (July 2013): 291-304; Hughes, The Fatal Shore, 257; Joy Damousi, “'Depravity and Disorder': The Sexuality of Convict Women," Labour History, no. 68 (1995): 30-45, https://doi.org/10.2307/27516352.

${ }^{50}$ Frances, Selling Sex : A Hidden History of Prostitution, 15.

${ }^{51}$ Damousi, “'Depravity and Disorder': The Sexuality of Convict Women."
} 


\section{Identity in the Life Archive}

Sources on female convicts transported to Australia come from administrative archives maintained by the governments of the United Kingdom and Australia, journals written by sailors, convicts, and officials, and newspapers from the imperial core and the fledgling colony. Because this thesis was written during the COVID-19 pandemic, some of these sources were inaccessible, such as the Home Office papers in the UK National Archives, which contain massive amounts of primary information on "police, prisons, prostitution, public order" that has not yet been digitized. Additional sources that would normally be accessible through the Interlibrary Loan (ILL) program were not available due to the program being on pause.

However, the archive containing much of the primary information for this thesis, the Old Bailey Online, is fully digitized. London's Central Criminal Court, commonly referred to by the street it resides on, Old Bailey, published its court proceedings eight times a year between 1674 and 1834 , creating a trove of 100,000 individual trials and over 600,000 pages of text, in total "the largest single source of information about non-elite lives ever published." ${ }^{52}$ Originally only available as an almost infinite series of hardback books or a collection of 38 reels of microfilm, the Old Bailey Proceeding were digitized between 2003-2005, allowing easy digital access to all surviving editions of the proceedings in a searchable database format. At the time of its initial release it constituted one of the largest XML databases in existence.

As a collection of trial transcripts, the Old Bailey Sessions Papers (OBSP) provide a wealth of information on the criminal law, proceedings, and sentencing in London in the periods it documents, allowing extensive analysis of changes over time in proceedings. It also constitutes

\footnotetext{
${ }^{52}$ Tim Hitchcock and Robert Shoemaker, "Digitising History From Below: The Old Bailey Proceedings Online, 1674-1834: The Old Bailey Proceedings Online, 1674-1834," History Compass 4, no. 2 (March 2006): 193-202, https://doi.org/10.1111/j.1478-0542.2006.00309.x.
} 
one of the largest archives of British social history in existence. In the words of the project's directors, "[The proceedings] describe life on the streets and in pubs, coffee houses, workplaces and lodgings; and they open a window onto the experiences of Londoners of all ages, classes and backgrounds." ${ }^{53}$ For the careful historian, the proceedings can be a window into communities and subcultures in London that didn't have the ability to produce their own archives, such as sex workers.

\section{CHARLOTEE BROWN, ELIZABETH HINCKS.}

Theft: theft from a specified place.

\section{3th January 1808}

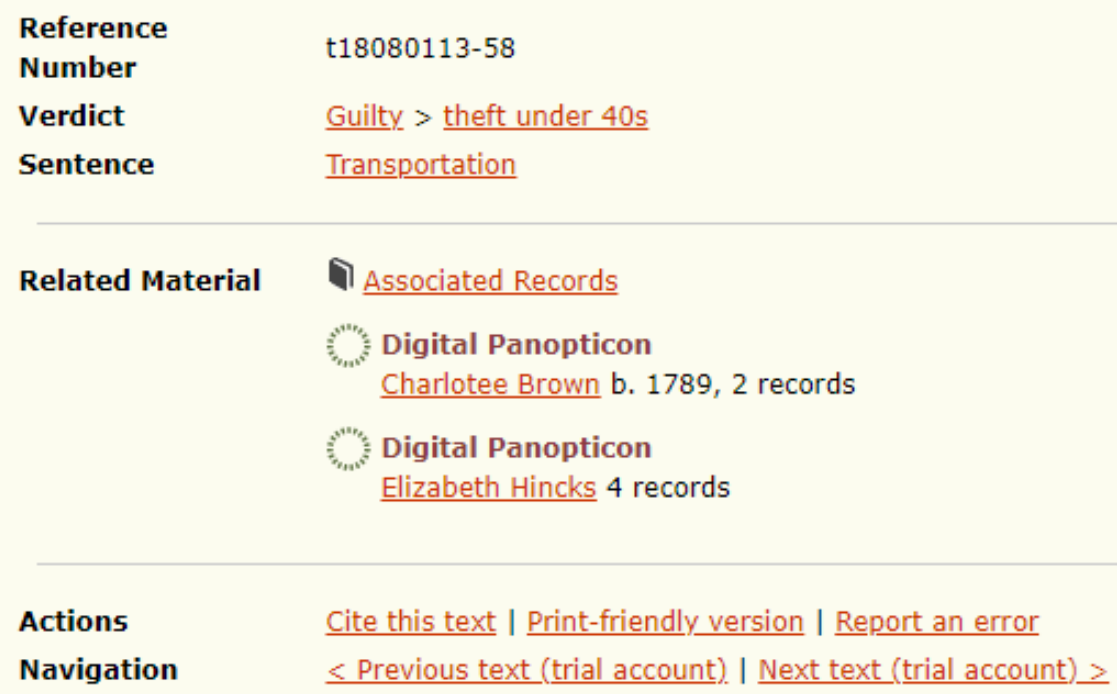

Trial summary from the Old Bailey Online ${ }^{54}$

This window is complicated, however, by the nature of the archive. The transcripts of the OBSP reflect the views, prejudices, and biases of London at the time, but also the particular biases of judges, court reporters, and other officials. This means that analyzing any singular term

\footnotetext{
${ }^{53}$ Hitchcock and Shoemaker, 193.

${ }^{54}$ Old Bailey Proceedings Online (www.oldbaileyonline.org, version 8.0, 04 June 2021), January 1808, trial of CHARLOTEE BROWN ELIZABETH HINCKS (t18080113-58).
} 
searchable within the archive is an exercise in dissecting cultural, class, and gendered context. It also means understanding the nuance of charged terminology contemporary to the time. For example, a search for "gay" or "homosexual" within the archive returns zero results, while "sodomy" return 147 results and "buggery" returns 42 results. However, the historian must then interpret the overlap between modern day terminology and the often imprecise language used to describe sexual deviancy at the time. This is even more difficult in the case of sex work, which was not a formal crime tried at the Old Bailey. The closest approximate crime is "keeping a brothel," which women made up about a third of those prosecuted for the crime. Among women transported to Australia, about $20 \%$ were noted as prostitutes either directly or through the euphemism "on the town." However, many more poor women in London resorted to sexual barter to meet their basic needs, in some female industries as many as $50 \%$ of women. ${ }^{55}$ Because prostitution was not a prosecutable crime in London, the evidence of sex workers and their lives appears in fragments in the transcripts of trials of others crimes, notably theft. It is in sifting through the archive that the distinctions between sex work, "deviancy" and the criminalization of women's agency becomes murky. In "Why They Stole: Women in the Old Bailey 1779-1789," MacKay argues that female theft patterns moved "according to different rhythms" than their male counterparts, due to borrowing practices and an "ethos of mutuality" that landlords and borrowing partners sometimes misconstrued as theft or used to their advantage. Additionally, different patterns of labor and settlement between women and men which led to women being more closely tied to their neighborhoods, making them more likely to be prosecuted for stealing from someone they knew. Women also stole different items than men, leaning heavily towards clothes and household items, but also money, watches, and jewelry,

\footnotetext{
${ }^{55}$ Frances, Selling Sex : A Hidden History of Prostitution, 9.
} 
which McKay argues can be attributed to the high frequency of theft accusations against prostitutes made by their clients. ${ }^{56}$

The vague Victorian notion of "whores" means determining that any particular woman on trial in the OBSP is a prostitute is exceedingly difficult, unless she identifies herself as such. The term, on an individual level, meant very little, especially because it was not a prosecutable crime. Instead, "whore" and "prostitute" should be viewed as sociocultural terms used to connect female agency to deviancy, through a linkage between the commercial sex trade and the more general conception of immoral sexual acts. As Ruth Mazo Karras has argued in the context of medieval England, prostitution became a way to use "the marginalization of some women so that others might be considered respectable." ${ }^{57}$ In the Victorian era, this carried an undeniable element of racialization, as prostitution became inexrably tied to outbreaks of venereal disease among British soldiers, particular in the Indian subcontinent. ${ }^{58}$ In this framework, tying a woman on trial to prostiution is not a specific criminal allegation, but an attempt to associate the woman with social deviance or impurity.

References to working "on the town" often appear in the defence statements made by women tried at the Old Bailey. These frequently take the shape of accusing the prosecution of either attempting to buy sex or traffic the female defendant, to the effect of casting doubt on the accusing party's accusations. In an 1806 coining (counterfeit) trial where was accused of counterfeiting a single shilling, Martha Doyle defended herself by saying that her mother was dead and her father "cruelly told to go on the town and to get my living as I could." She told the court that she took the advice and "met with a gentleman" for twelve shillings, which she found

\footnotetext{
${ }^{56}$ L. MacKay, "Why They Stole: Women in the Old Bailey, 1779-1789," Journal of Social History 32, no. 3 (March 1, 1999): 623-39, https://doi.org/10.1353/jsh/32.3.623.

${ }^{57}$ Karras, Common Women : Prostitution and Sexuality in Medieval England.

${ }^{58}$ Levine, Prostitution, Race, and Politics.
} 
out later were counterfeited, but out of desperation tried to use anyway. The court found her defense unconvincing and sentenced her, at 17, to death. Her sentence was later respited to 21 years transportation, on the Speke..$^{59}$

In Martha Doyle's case, her appeal was based on the idea of sex work as a last resort, to the point where her own father had turned her out onto the street. In other cases, women denied any attachment to sex work at all, or argue that they were forced into prostitution under the pretense of being a live-in servant. But in most cases, the formula was as follows: the presiding judge asks the accusing party or witness "what is the prisoner" and the party replies "on the town" or "an unfortunate girl of the town," and no denial is written in the transcript. ${ }^{60}$ This does not necessarily reflect a tacit admission from the woman in question, as testimony and defenses from women were recorded less often and less accurately than those of men.

In addition to the OBSP, another archive used in this work is the Digital Panopticon. The Panopticon is particularly useful because rather than an archive of trials, it's an archival recreation of individual lives. Merging four million individual records from OBSP, Australian archives of prisoner arrivals, marriages, and deaths, and private family history companies like Ancestry and FindMyPast that is normally only available behind paywalls, the Panopticon is a fully searchable database of 90,000 convicts recorded from 1780-1925. Each convict with more than one record is assigned a "life archive" page, meaning that, for thousands of convicts, the information about their trial, transportation, and arrival is viewable on a single page. The project has provided previously unthinkable access to the lives of individual convicts, and has made tracing the fate of convicts and interpreting their lives vastly easier.

\footnotetext{
${ }^{59}$ Old Bailey Proceedings Online (www.oldbaileyonline.org, version 8.0, 27 April 2021), July 1806, trial of MARTHA DOYLE (t18060702-32). The Digital Panopticon Martha Doyle b. 1789, Life Archive ID obpt18060702-32-defend317 (https://www.digitalpanopticon.org/life?id=obpt18060702-32-defend317). Version 1.2.1, consulted 27th April 2021.

${ }^{60}$ Old Bailey Proceedings Online (www.oldbaileyonline.org, version 8.0, 29 April 2021), December 1800, trial of MARY SWAINE (t18001203-57); May 1805, trial of SARAH BRIANT (t18050529-62).
} 
One interesting dimension of an archival project like the Digital Panopticon is the ease with which it facilitates tracking cohorts of convicts, whether it be women who were transported on the same ship, sentenced on the same day, or assigned to the same work program. Although outside the scope of this thesis, using the Digital Panopticon it would be possible to track the lives of most if not all women transported on a single ship like the Speke, which transported 99 female convicts from England to Port Jackson in New South Wales in 1808. Such projects expand historical knowledge of the lives of transported women and the pathways that led women to marriage, the workhouse, Tasmania, and other destinations.

Bound up in these archival projects are the many human perspectives and human hands it took to transform contemporary documents printed in the Old Bailey and other archives into a searchable matrix. Viewing any singular "life archive" within the Digital Panopticon means hearing traces of the original producer(s) of the document, the people that laboriously digitized the document (and the programs that helped them) and the people who then compiled those documents into searchable databases. In each layer of this process a new meaning is embedded, a new trace is added to the archive. Notably, at very few junctures in this process is the voice of the woman being documented recorded, even as we reach further and continuously develop the archive to understand her perspective. Reaching an understanding of the sentence of transportation as it was imposed on women means recognizing the precariousness of an archive that doesn't take into account the voices of its subjects, or marginalizes their voices when they can be heard, and the inevitability of its actors slipping through the "cracks." It means recognizing, in the words of Verne Harris, that "...records do not speak for themselves. They speak through the taxonomies that categorise them." ${ }^{\prime 61}$

\footnotetext{
${ }^{61}$ V. S. Harris, Ghosts of Archive: Deconstructive Intersectionality and Praxis, Routledge Studies in Archive (London; New York: Routledge, Taylor \& Francis Group, 2021), 50.
} 
One way of conceptualizing the archive and the "cracks" created by both record and its taxonomies is through the microhistorical method. As Jeremy Boulton observed in his study of the life of Elizabeth Laroon, daughter of a seventeenth century English painter, analyzing the life of a singular common person reveals “the identity — or perhaps more properly 'identities' — of 'the poor.'" His analysis of Laroon's traces in the archive of London poorhouses followed her to a hospital used "almost exclusively" to treat female patients with venereal disease, then known as the "foul disease." He posits, based on her stay in this hospital and her being treated by a nurse who disproportionately treated patients with the "foul disease," that Laroon "almost certainly" contracted venereal disease. Boulton's approach is noteworthy because of the depth with which he's able to read into the archive of metropolitan London, finding knowledge that is explicitly hidden or obscured, and pull out the likely life of an unfortunate woman. He argues that Laroon's relatively wealthy upbringing and her sudden plunge into the parish poor law system demonstrates the vulnerability of the single woman in London's early eighteenth-century "economy of insecurity." This, enmeshed with attitudes and understandings of venereal disease, created a system where unmarried women were punished for each subsequent misfortune they fell upon. It's this system of punishment that creates the archival traces of these women's lives, with each police contact and poorhouse admission creating a new point in a "foul" woman's life archive. $^{62}$

Understanding that microhistory can reveal the "identities" of the poor, and that archival traces are interactions with a particular system of punishment and socialization, archives like the Old Bailey Online and the Digital Panopticon that categorize evidence around the individual should be viewed with caution, because they are not recreating the identities of an individual so

\footnotetext{
${ }^{62}$ Jeremy Boulton, “The Painter's Daughter and the Poor Law: Elizabeth Laroon (b. 1689 -Fl.1736)," The London Journal 42, no. 1 (January 2, 2017): 13-33, https://doi.org/10.1080/03058034.2016.1266184.
} 
much as the identities that were projected onto them. By organizing records from jails, courts, convict ships, and penal institutions and colonies, we gain a number of descriptors such as "prisoner", "unmarried", “on the town", "foul”, etc. But these descriptors are not tied to any identity established by the individual, they are projections, archival traces created by others to assign meaning to the individual. These descriptors can be given some credence, but they have to be regarded as less than the full truth, and far from a full archival recreation of an individual. 


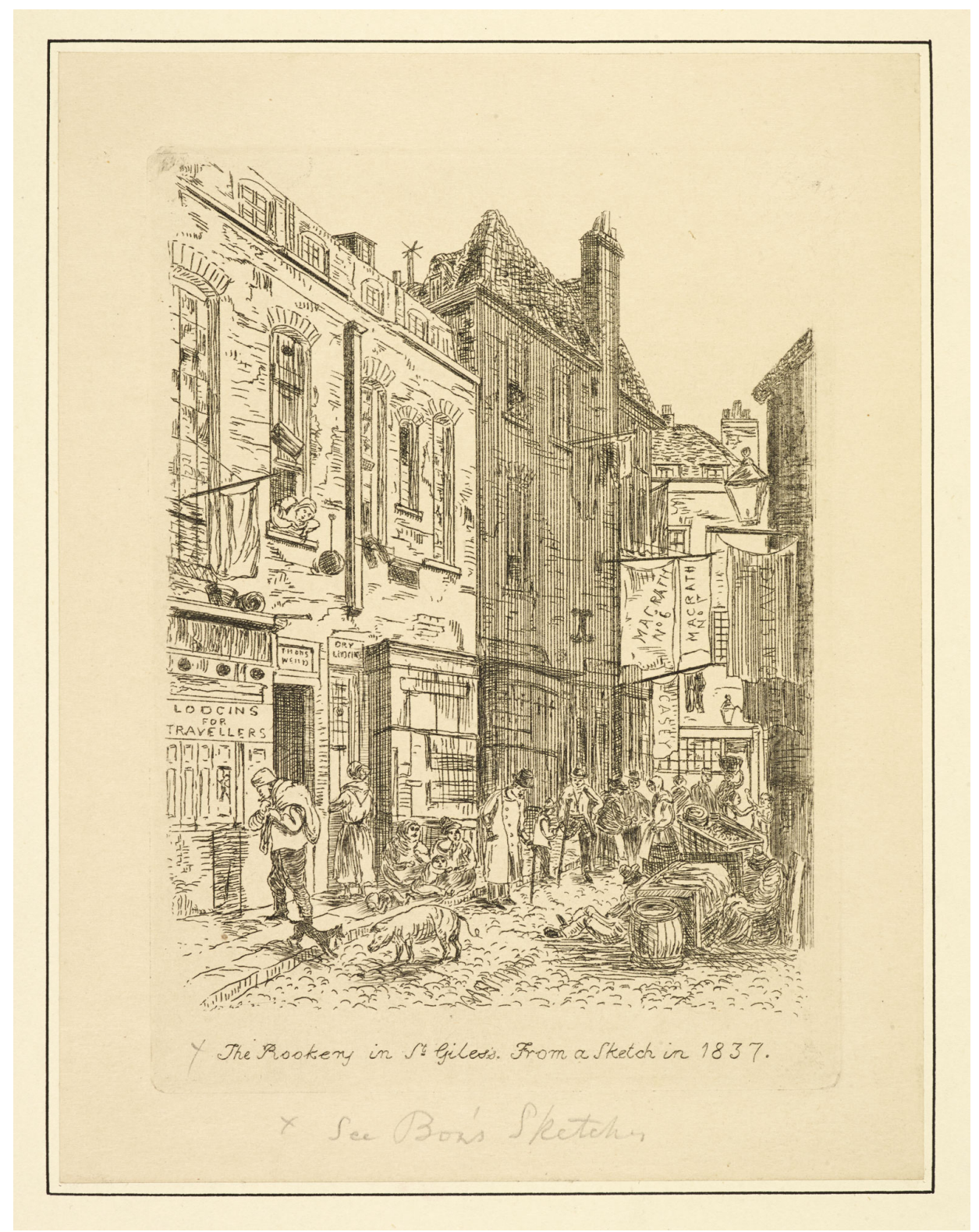

St. Giles in the Fields ${ }^{63}$

\section{Case Study: Elizabeth Hincks and Charlotte (Charlotee) Brown}

The parish of St.Giles in the Fields was home to London's infamous Rookery, "the most notorious set of mean streets London had ever known," a slum that had been failed by city officials, urban developers, parish workers, and just about everyone else. Much as poor women

${ }^{63}$ Forster, John. "Printed Sketch of The Rookery in St Giles, 1817," 1817. British Library. London. 
were marked with archival traces like "foul", "on the town" and "unfortunate", the Rookery was marked with words like "dark", "stench", "hovel", "filth", “dirt", "damp", "swarms", and "infested", words that suggested an "urban bourgeois projection" onto a space in need of improving. According to Robert Shoemaker, St Giles had the highest rate of petty offenses of any parish in London in the eighteenth century, a marker not just of crime rates but of urban tension and policing practices. By the nineteenth century the Rookery had become associated with transience, informal work, and prostitution. For these reasons, combined with St. Giles serving as a key international migration point into London, St. Giles was a hotspot for purveyors of short-term accommodations, in the form of dwelling houses. Such spaces often facilitated sex work on the side. ${ }^{64}$

All the cultural understandings of the Rookery and its image among the upper and middle classes of London as a place "too dangerous to enter" would have been extremely familiar to the all-male Middlesex Jury and sitting judge, Recorder John Silvester, presiding over the trial of Elizabeth Hincks, 21, and Charlotte Brown, $19 .{ }^{65}$

At Old Bailey, the jury for each jurisdiction sat over all the trials scheduled for that day, rather than a singular trial. Chosen from a pool of fifty property-owning men early that morning, the group of twelve men, almost all of them first time jurors, had committed to a marathon of cases read in rapid procession. In total they had heard 29 trials, most of them theft charges, before reaching Hincks and Brown. Judges before the first middlesex jury had already sentenced eight people to death that day, including a thirteen year old boy for stealing a spool of velveteen. Five others had been sentenced to transportation, a majority of them women convicted of theft

\footnotetext{
${ }^{64}$ Adam Crymble, "The Decline and Fall of an Early Modern Slum: London's St Giles 'Rookery', c. 1550-1850," Urban History, 2021, 1-25, https://doi.org/10.1017/S0963926821000183.

${ }^{65}$ Brown appears under both "Charlotee" and "Charlotte" in the trial transcript. I use the more common Charlotte here for convenience and readability.
} 
under 40 shillings. ${ }^{66}$ To say that justice at the Old Bailey was perfunctory is to understate the meat grinder-esque quality of the judicial system. Not only was justice perfunctory, it was cruel, it was brutal, and it was nearly random. ${ }^{67}$

Just like 24 First Middlesex defendants tried earlier that day, Elizabeth Hincks and Charlotte Brown had been accused of theft. The prosecutor (accuser) was Thomas Barry, a shoemaker staying at a dwelling house in St. Giles. Barry said that he had gone out on the night of Dec. 13, 1807 for a pint at the Spotted Dog, a pub and dwelling house, fallen asleep at some point, and when he woke up his watch, which he values at fifty shillings, was missing. He accused Charlotte Brown and Elizabeth Hincks of taking the watch "off his fob" while he drunkenly slept in the dwelling house. While relaying his version of events, he's questioned by the Silvester, who asks Barry "Did you pick up these women in the street?"

Barry denies that he "picked up" either Brown or Hincks, and they were recorded as offering no defense or witnesses, so the transcript offers no definitive answers about Brown and Hincks' relationship to prostitution, except that the court assumes they were prostitutes. After the court asks Barry if he picked up the women, he's asked how he could identify the woman at all if he was asleep when his watch was stolen. It's here that he produces his only witness, a Black man named Dolby Jackson. Jackson, who I wasn't able to find a record of outside of the court transcript, tells the court that he is a shoeblack (shoeshiner) and that he was sitting at the Black Dog, which we can assume is the same pub as what Barry calls the Spotted Dog, when he witnessed Thomas Barry come in with a friend, drink most of a pint, and then pass out.

Dolby Jackson then says that Charlotte Brown and Elizabeth Hincks came in, finished Barry's pint of beer, and leaned him over so that his head was resting in Brown's lap. They took

\footnotetext{
${ }^{66}$ Old Bailey Proceedings Online (www.oldbaileyonline.org, version 8.0, 04 June 2021), January 1808, trial of CHARLOTEE BROWN ELIZABETH HINCKS (t18080113-58).

${ }^{67}$ For "justice was perfunctory" see Christopher, Pybus, and Rediker, Many Middle Passages.
} 
turns searching him, according to Jackson, while talking about not being able to find anything and telling Jackson to be quiet while he called for help from the landlord. They found Barry's watch and went into the street. After that, Jackson says that he roused Thomas Barry, who went into the street and found the women drinking saloop, a coffee and tea alternative held out as an aphrodisiac and health tonic served in eighteenth and nineteenth century London coffeehouses. ${ }^{68}$ The imagery here is quite revealing of the picture Thomas Barry wants to paint of the accused. Having just casually strolled in and stolen an expensive watch off an unconscious man in the middle of the pub, these two prostitutes then sat just across the street drinking a hot beverage. The implication is that Hincks and Brown are calculated thieves, who have done this many times before and have no shame, anxiety, or fears of being caught.

Barry and his witness's testimony contains numerous details that don't fit neatly into this narrative. Barry describes waking up to another woman standing over him, who Jackson identified as an accomplice of Hincks and Brown. When he goes out onto the street and searches the two women and they don't have his watch, the mysterious extra woman becomes a convenient way to explain where his watch went. The woman also becomes a way to imply that Hincks and Brown are more criminally apt than anyone can prove. A disappearing accomplice pushes the narrative of a further degree of premeditation. Dolby Jackson also says in his testimony that "some of them in that public house stole my hat" worth twelve shillings, perhaps implying that the girls were part of a broader criminal enterprise.

After Jackson testifies, the court records that Hincks and Brown offered no defence or character witnesses. It's difficult to determine exactly why Hincks and Brown offered no defence. One possible explanation is simply that they did not think their testimony would sway the minds of the jurors. This would have been a rational action in a court where male testimony

68 "Saloop" in Cannon and Crowcroft, The Oxford Companion to British History. 
was overwhelmingly favored above female testimony, especially testimony by poor women. The fact that they had already been labelled as prostitutes and potential carriers of venereal disease would have only furthered their inability to be taken seriously.

There's no record in the OBSP of how long the jury took to deliberate, but based on their caseload for that day it did not take very long. They returned guilty verdicts for both Hincks and Brown. However, there is an unadmitted act of leniency in the sentencing imposed by the judge, Recorder John Silvester. Barry identified his watch as costing 50 shillings, but Hincks and Brown are convicted of "stealing to the value of thirty-nine shillings." This seemingly random reduction is extremely significant because of a 1713 statue passed during a panic about clergyable offenses. The statute made stealing a value greater than 40 shillings from a dwelling house a capital, nonclergyable offense. As executions became disfavored in the eighteenth century in favor of increasing penal options, judges would often use their discretion to reduce convictions down to non-capital offenses, in an act known as partial sentencing. And so Hincks and Brown were convicted of stealing just below the amount that would make their offense capital.

While it's impossible to read into how much gender impacted this specific decision, statistically, women were much less likely to be executed in eighteenth and nineteenth century England than men. Judges in front of the First Middlesex Jury had already sentenced four women to death that day, equal to the amount of men, so the reticence to hang women may not have factored into their decision making in the same way the averages suggest. It's also possible that they were assuming the sentence would be reduced or pardoned later in the criminal process, which was very common, especially for female convicts. ${ }^{69}$ Whatever the case, Hincks and Brown

\footnotetext{
${ }^{69}$ Beattie, Crime and the Courts in England; Clive Emsley, Tim Hitchcock, and Robert Shoemaker, "Historical Background - Gender in the Proceedings."
} 
were ruled "redeemable" enough to not face the death penalty in the eyes of the judge. This is partly because, unlike Martha Davis, who had been sentenced to death for highway robbery earlier that day, Hincks and Brown had not used violence during their crime. This distinction between violent theft and nonviolent theft was very important in the eyes of the court. Additionally, there is a distinction in victims. In the case of Martha Davis, her victim was a fifteen year old boy named Charles Titwell. In the eyes of the jury and judge he most likely made a more pitiable victim than a drunken shoemaker who had passed out in St. Giles.

After sentencing, Elizabeth Hincks sat in holding for two months, most likely first in Newgate Gaol and then either on a convict hulk or her transport ship, the Speke. It's somewhere in this two month period that she would have seen her accomplice, and probable friend, Charlotte Brown for the last time. Unlike Hincks, Brown was never transported to Australia. I was unable to find a record of her pardon, which would be located in the UK Archive's Home Office files. What we do have is a record of discharge from a London workhouse in 1826 for a Charlotte Brown with the same birthdate as the one on trial. The Shoreditch Workhouse recorded Brown as staying for roughly four months, and notes on her file "With 2/ apr of Shoes and Clothes for the children." ${ }^{.70}$ It's not clear if the shoes and clothes are for her children, or some other set of children. It's also not verifiable, within the scope of this thesis, if this is indeed the same Charlotte Brown. This is part of the issue with arranging records into a "life archive," especially in the case of nineteenth century England, where many given names and surnames were extremely common. In many cases the best the historian can do is assign archival descriptors to a singular person based on a series of likelihoods, including place, time, and sequence of events.

And so in likelihood, Charlotte Brown never saw her friend Elizabeth Hincks again. Just as both women had been deemed redeemable enough to not receive the death penalty, the system

${ }^{70}$ London Metropolitan Archives; London, England; Reference Number: P91/LEN/1336 
had decided Brown was worthy to stay in London. There are infinite possible reasons why she was granted a pardon while Hincks wasn't. Perhaps she had some assistance navigating the legal system that Hincks didn't. Perhaps because Brown was 19 while Hincks was 21 she was able to convince the system that she was less wicked than her counterpart, or even that she had been an accomplice to Hincks. The pardon system provided enormous discretion to judges and without a record there's no way to narrow down the possibilities. Whatever the case, Brown was not banished to Australia to make a new life. She stayed in London and, much like Elizabeth Laroon a century before her, was supported by the poor law system. She may or may not have been treated for venereal disease, and she may have had children outside the workhouse that she supported through legal and extralegal labor. If she stole or otherwise committed a crime at a later point in her life, she did not get hauled in front of the Old Bailey again.

Hincks, the older of the two young women, was not granted the pardon that Brown was. After being held for two months in Newgate, with filthy conditions and meager provisions, she boarded the Speke, a privately owned ship contracted to transport 99 female convicts to Australia. The Speke took the usual route to Australia, a "long and tedious" eight month journey which included stops in Rio De Janeiro and Cape Horn. In addition to dancing, singing, and possibly reading, Hincks would have been "kept busy" with sewing and needlework provided either by the ship's owner or a charitable organization. It's possible she was allowed to sell the articles she sewed for money once the ship reached Australia, although when the raw materials were provided by the owner the final products and profits went back to him. ${ }^{71}$

On the Speke there were also male sailors and crewmembers who had spent the past decade in a sociocultural environment that portrayed female convicts as whores and their transport ships as brothels. In reality, the sexuality of female convicts was much more nuanced.

\footnotetext{
${ }^{71}$ Bateson, The Convict Ships, 1787-1868., 77.
} 
Hincks would have navigated a complicated gendered landscape where juxtapositions were made between the "order" of public spaces and the "disorder" of private spaces. In 1808, female convict ships were still relatively unregimented spaces, which would have provided ample opportunities for sexual liaisons between crewmates and convicts. Hincks appears to have not gotten pregnant onboard the Speke, which is not to say she did not engage in sex with crewmembers, but that there is no way to know for certain if she did or not. Here the haziness in the archive, specifically the information that British officials found pertinent to write down, provides a measure of cover for Hincks. Without an archival trace, a birth or marriage record in this case, this part of her past is hidden to the historian.

The next time Hincks appears in the archive is a year and a half later on April 8, 1810, the day she married John Moss, a fellow transported convict, and the day their daughter Rebecca was baptized. Rebecca's birthday is recorded on the baptism certificate as December 5, 1809, meaning that Hincks and Moss began their relationship in February or March of 1809 at the latest, just three months after Hincks arrived on the Speke. Moss, who was transported to New South Wales aboard the Pitt at the age of 14 for stealing a hat from another 14 year old boy, had been in Australia since 1792, 16 years before Hinck's arrival. By the time he met Hincks he had already served his seven year sentence and was a free man and local constable. That is to say, he had a relatively high standing in his community. Given this, it's likely that he chose Elizabeth Hincks as a convict "assigned" to him as soon as she arrived. ${ }^{72}$

The assignment system meant that legally speaking, Hincks was a convict working for John Moss as a servant. In reality, governors and lower officials realized that the system functioned as a bride market for colonial officials, seamen, and freed colonists, and later made

\footnotetext{
72 "Classified Advertising," Sydney Gazette and New South Wales Advertiser (NSW : 1803 - 1842) (NSW, December 27, 1817), http://nla.gov.au/nla.news-article2177658.
} 
attempts to regulate it as such. Moss, as a freed colonist, would have needed permission to be assigned a female convict. Seeking that permission, and then affirmatively choosing Hincks, leaves little doubt that Moss was happy with the arrangement. There's significantly more to the question of Hinck's happiness and consent to the relationship.

As discussed in an earlier section, marriage in New South Wales allowed both freed male convicts and female convicts new opportunities and abilities to exert control over their lives. For women, assignment was the only option available besides the Female Factory, an extremely unpleasant alternative. And even if they chose that alternative, the factory also functioned as a secondary bride market, although women used the norms and rules of the factory and assignment system to assert some influence over who they ended up under the control of. Marriage was also one of few ways an Australian woman could avoid the label "damned whore" and the policing and mistreatment that that label carried. Victorian sensibilities clashed with the public discourse and concern around prostitutes and "damned whores" to create a series of pressures guiding women towards Christian marriage and motherhood. Even if Hincks was not assigned to Moss and entered into an informal arrangement with him, it's hard to read any level of consent into the archive. Marriage was a choice made under duress. As with all of Hinck's life, her opinion on the matter was not written down. The closest thing to proof of consent is a single thumbprint she left on the marriage certificate. 


\section{Conclusion: The Limits of a Reconstructed Life}

The lives of Charlotte Brown and Elizabeth Hincks raise a number of questions about "redemptions" in the context of a global settler colonial empire defining the role of white women, particularly poor white women, in the imperial project in the early nineteenth century. As Frances remarked in Selling Sex: A Hidden History of Prostitution, the early nineteenth century was a time of "increasing emphasis on notions of respectability" tied to a specific model of family and domesticity. This coalescing view of (white) domesticity, as historians of empire and gender have argued, was inherently rooted in the imperial project. How do Hincks and Brown fit into this project? What is the significance of following women through an archive constructed by an empirical entity, one intent on resource extraction and unending expansion? And how much does an understanding of prostitution and colonial anxieties explain the lives of these two women? To answer that we must contextualize their experiences in a larger framework.

Before 1837, there was a brief period where Black Carribeans, mostly former slaves, could be transported to Australia via the British Empire for certain crimes. Similar to transported convicts from England and Ireland, these crimes were mostly property crimes such as theft, poaching, and robbery. This practice ended in 1837 when colonial officials in England came to understand the aims of the empire in the Carribean and Australia, and the two populations, as inherently different and not to be mixed. There was an understanding that the subjugation of Black people was not the same as the subjugation of white, mostly Anglo-Saxon convicts. The social and legal "redemption" that a white woman could obtain through marriage, that she was pressured to obtain through marriage, was not extended to Black people. There was no redemption for lesser subjects of the British Empire, no eventual land grant or right to seek office for male convicts and no hope of becoming the ideal mother and homemaker for the female 
convict. For non-white residents of the British Empire there was only labor and extraction. This is not to say that Hincks and Brown were not mistreated, or that their lives were not upended by a judicial system that viewed them as foul prostitutes. That is true. Rather, they were viewed as foul prostitutes capable of redemption and reform into domestic womanhood. For Charlotte Brown, some aspect of her character, age, or femininity made her worthy of redemption in England, through the workhouse system. For Hincks, this redemption was in Australia, through Christian marriage and motherhood. But the point is that redemption was possible. It was hard-earned, imperfect, and at times extremely alienating, but it existed. In 1837, colonial officials made it clear that there was no such redemption possible for Black Caribbeans, or any colored subject of the empire. ${ }^{73}$

Then there's the archival question of redemption and equity. The access to court records, ship manifests, workhouse discharges, marriage certificates, and other documents used in this thesis are available because my subjects, Hincks and Brown, were residents of the imperial core. There's no comparable Old Bailey Online or Digital Panopticon for the residents of many of Britain's colonies, even those where dissent was quashed and heavily policed. The use of state-produced archives to recreate individual lives is an ability that is not equally available to all subjects of a particular bureaucracy. The archival traces left of Hincks and Brown record their interactions with the bureaucracy, but they also signify the bureaucracy assigning a meaning or value to Hincks and Brown. Others, such as Dolby Jackson, the Black Londoner who testified against Hincks and Brown, are not recorded nearly as much and are significantly harder to recreate or "redeem" than the subjects of this thesis. ${ }^{74}$

\footnotetext{
${ }^{73}$ Diana Paton, “An 'Injurious' Population,” Cultural and Social History 5, no. 4 (December 1, 2008): 449-64, https://doi.org/10.2752/147800408X341659.

${ }^{74}$ I would like to thank the numerous living descendants of Elizabeth Hincks Moss, who have traced the arc of her life with remarkable precision on family history websites like Ancestry.com.
} 


\section{Bibliography}

“Absorb The Aborigines, Says Expert.” Herald (Melbourne, Vic. : 1861 - 1954). Melbourne, Vic., January 13, 1949. http://nla.gov.au/nla.news-article247723979.

Arnot, Meg, Margaret L Arnot, and Cornelie Usborne. Gender and Crime in Modern Europe. London: UCL Press, 1999.

Bateson, Charles. The Convict Ships, 1787-1868. [2d ed.]. Glasgow: Brown, Son \& Ferguson, 1969.

Beattie, J. M. Crime and the Courts in England: 1660 - 1800. Oxford: Clarendon [u.a.], 1986.

Boulton, Jeremy. "The Painter's Daughter and the Poor Law: Elizabeth Laroon (b. 1689 -Fl.1736)." The London Journal 42, no. 1 (January 2, 2017): 13-33. https://doi.org/10.1080/03058034.2016.1266184.

Britannica, T. Editors of Encyclopaedia. “The Dreaming.” In Encyclopedia Britannica, November 2, 2020.

Cannon, John, and Robert Crowcroft, eds. The Oxford Companion to British History. Second edition. Oxford, United Kingdom; New York, NY: Oxford University Press, 2015.

Christopher, Emma. Merciless Place: The Fate of Britain's Convicts after the American Revolution. Cary, UNITED KINGDOM: Oxford University Press, Incorporated, 2011. http://ebookcentral.proquest.com/lib/psu/detail.action?docID=829359.

Christopher, Emma, Cassandra Pybus, and Marcus Rediker, eds. Many Middle Passages: Forced Migration and the Making of the Modern World. The California World History Library 5. Berkeley: University of California Press, 2007.

"Classified Advertising." Sydney Gazette and New South Wales Advertiser (NSW : 1803 - 1842). NSW, December 27, 1817. http://nla.gov.au/nla.news-article2177658.

Clive Emsley, Tim Hitchcock, and Robert Shoemaker. "Historical Background - Gender in the Proceedings." Old Bailey Proceedings Online. Accessed April 26, 2021. https://www.oldbaileyonline.org/static/Gender.jsp.

Coad, John and Chiswick Press. A Memorandum of the Wonderful Providences of God to a Poor Unworthy Creature: During the Time of the Duke of Monmouth's Rebellion and to the Revolution in 1688. xiii, 141, 14 p. London: Longman, Brown, Green \& Longmans, 1849. //catalog.hathitrust.org/Record/000313724. 
Conway, Jill. “Gender in Australia.” Daedalus, 1985, 343-68.

Cook, James. Captain Cook's Journal During His First Voyage Round the World Made in H. M. Bark "Endeavour", 1768-71. Project Gutenberg, n.d.

Crymble, Adam. “The Decline and Fall of an Early Modern Slum: London's St Giles 'Rookery', c. 1550-1850." Urban History, 2021, 1-25. https://doi.org/10.1017/S0963926821000183.

Curthoys, Ann. "Gender Studies in Australia: A History.” Australian Feminist Studies 15, no. 31 (2000): 19-38.

Damousi, Joy. "Chaos and Order: Gender, Space and Sexuality on Female Convict Ships." Australian Historical Studies 26, no. 104 (April 1995): 351.

—_ "'Depravity and Disorder': The Sexuality of Convict Women.” Labour History, no. 68 (1995): 30-45. https://doi.org/10.2307/27516352.

Frances, Raelene. Selling Sex : A Hidden History of Prostitution. Sydney, AUSTRALIA: University of NSW Press, 2007.

http://ebookcentral.proquest.com/lib/psu/detail.action?docID=421330.

Glenn, Evelyn Nakano. "Settler Colonialism as Structure: A Framework for Comparative Studies of U.S. Race and Gender Formation." Sociology of Race and Ethnicity 1, no. 1 (2015): 52-72. https://doi.org/10.1177/2332649214560440.

Haley, Sarah. No Mercy Here: Gender, Punishment, and the Making of Jim Crow Modernity. Justice, Power, and Politics. Chapel Hill: The University of North Carolina Press, 2016.

Harris, V. S. Ghosts of Archive: Deconstructive Intersectionality and Praxis. Routledge Studies in Archive. London; New York: Routledge, Taylor \& Francis Group, 2021.

Heidensohn, Frances. "The Deviance of Women: A Critique and an Enquiry: The Deviance of Women." The British Journal of Sociology 61 (January 14, 2010): 111-26. https://doi.org/10.1111/j.1468-4446.2009.01242.x.

Hitchcock, Tim, and Robert Shoemaker. "Digitising History From Below: The Old Bailey Proceedings Online, 1674-1834: The Old Bailey Proceedings Online, 1674-1834.” History Compass 4, no. 2 (March 2006): 193-202. https://doi.org/10.1111/j.1478-0542.2006.00309.x.

Hughes, Robert. The Fatal Shore. 1st Vintage Books ed. New York: Vintage Books, 1988.

Jones-Rogers, Stephanie E. They Were Her Property: White Women as Slave Owners in the American South. New Haven; London: Yale University Press, 2019.

Karras, Ruth Mazo. Common Women : Prostitution and Sexuality in Medieval England. New 
York, UNITED STATES: Oxford University Press, Incorporated, 1996. http://ebookcentral.proquest.com/lib/psu/detail.action?docID=1591264.

Kiernan, Ben. Blood and Soil: A World History of Genocide and Extermination from Sparta to Darfur. New Haven, Conn. London: Yale University Press, 2009.

King, Peter. "Gender, Crime and Justice in Late Eighteenth and Early Nineteenth-Century England.” In Gender and Crime in Modern Europe. London: UCL Press, 1999.

Levine, Philippa. Prostitution, Race, and Politics: Policing Venereal Disease in the British Empire. New York: Routledge, 2003.

_ . "Rereading the 1890s: Venereal Disease as 'Constitutional Crisis' in Britain and British India." The Journal of Asian Studies 55, no. 3 (1996): 585-612. https://doi.org/10.2307/2646447.

MacKay, L. "Why They Stole: Women in the Old Bailey, 1779-1789." Journal of Social History 32, no. 3 (March 1, 1999): 623-39. https://doi.org/10.1353/jsh/32.3.623.

Madley, Benjamin. "From Terror to Genocide: Britain's Tasmanian Penal Colony and Australia's History Wars.” Journal of British Studies 47, no. 1 (2008): 77-106.

Mulvaney, D.J. “The Australian Aborigines 1606-1929: Opinion and Fieldwork." Historical Studies: Australia and New Zealand 8, no. 30 (May 1958): 131-51. https://doi.org/10.1080/10314615808595109.

Nolan, Bláthnaid. "Up Close and Personal: Lesbian Sub-Culture in the Female Factories of Van Diemen's Land." Journal of Lesbian Studies 17, no. 3/4 (July 2013): 291-304.

Paton, Diana. “An 'Injurious' Population.” Cultural and Social History 5, no. 4 (December 1, 2008): 449-64. https://doi.org/10.2752/147800408X341659.

Pitman, Henry. A Relation of the Great Sufferings and Strange Adventures of Henry Pitman, Chyrurgion to the Late Duke of Monmouth, Containing an Account ... London, Printed by Andrew Sowle, and are to be sold by John Taylor ..., 1689.

http://stats.lib.pdx.edu/proxy.php?url=http://search.proquest.com/books/relation-great-suf ferings-strange-adventures/docview/2240855559/se-2?accountid=13265.

Rees, Siân. The Floating Brothel: The Extraordinary True Story of an Eighteenth-Century Ship and Its Cargo of Female Convicts. 1st ed. New York, N.Y.: Hyperion, 2002.

Rushton, Peter, and Gwenda Morgan. "Running Away and Returning Home: The Fate of English Convicts in the American Colonies." Crime, Histoire \& Sociétés / Crime, History \& Societies 7, no. Vol. 7, n² (December 1, 2003): 61-80. https://doi.org/10.4000/chs.545. 
Scott, Joan W. "Gender: A Useful Category of Historical Analysis.” The American Historical Review 91, no. 5 (1986): 1053-75. https://doi.org/10.2307/1864376.

Smith, Abbott Emerson. Colonists in Bondage: White Servitude and Convict Labor in America, 1607-1776. Chapel Hill, UNITED STATES: University of North Carolina Press, 2012. http://ebookcentral.proquest.com/lib/psu/detail.action?docID=4322215.

Unknown. "Broadside about a Lecture 'on the Horrors of Transportation,"” 1849. British Library.

Walkowitz, Judith R. Prostitution and Victorian Society: Women, Class, and the State. Cambridge ; New York: Cambridge University Press, 1980.

Wolfe, Patrick. "Settler Colonialism and the Elimination of the Native." Journal of Genocide Research 8, no. 4 (December 2006): 387-409.

https://doi.org/10.1080/14623520601056240. 